\title{
FEMINIST CULTURAL LITERACY: TRANSLATING DIFFERENCES, CANNIBAL OPTIONS
}

Sneja Gunew University of British Columbia, Canada

\section{Prologue}

In trying to write this paper over several months last year for a collection of essays examining the current state of feminism and women's studies I was mystified by my internal resistance to the project. After all, feminism and Women's Studies have been part of my life for over two decades. As part of the process of deferral, as though waiting for a sign, I was musing about this paper while in Budapest at the end of May 1999 when the war in Kosovo and the former Yugoslavia seemed to escalate daily. The occasion was a feminist conference being held at the Central European University (an institution set up by the Soros Foundation as part of its grand plan to facilitate the creation of 'open societies'). The conference's title was 'Pleasure and Power' and the ironies were manifold, not least of which the knowledge that we were engaging in an 'open society' project on the threshold of war. How could we come to terms with the disaster on our doorstep - war as the most extreme fracturing of the social, the ultimate symbol of a closed society? What could feminism offer here?

\begin{tabular}{|l|l|l|l|l|}
\hline Ilha do Desterro & Florianópolis & $n^{\circ} 44$ & p.153-180 & jul./dez. 2003 \\
\hline
\end{tabular}


The participants were drawn in the main from other parts of eastern and central Europe, though to my knowledge no Albanians were present there. At the conference the dominant theoretical paradigm was that of psychoanalysis in the particular versions in which it is applied to cultural analyses. I pondered this phenomenon. Discussions concerning race and ethnicity or references to multiculturalism were conspicuous by their absence, particularly for those of us from the socalled first world who are used to such interrogations in the conferences we attend. Psychoanalysis can after all be used as a way of analyzing individual relations without ever having to embed them in a sociopolitical context, in spite of the fact that it is precisely in eastern Europe that theorists such as Slavoj Zizek and Renata Salecl have brilliantly attempted to change this. ${ }^{1}$ We conference delegates represented our nations in a broad sense but were not segmented into any further subgroups. Indeed, it was difficult to raise the issue of sub-groups or of ethnicity, or of processes of racialization or multiculturalism. The proximity of Kosovo was palpable and ultimately unspeakable both in its own right and in the ways that it made certain conversations impossible, particularly public ones. Yet, in spite of our many differences and the ensuing silences I've tried to indicate, a tenuous sense of a shared project prevailed and that project continues to be named as feminist. That feeling of commonality riven by differences was to me an enigmatic and fragile but none the less palpable image of continuity and I was able to place it alongside the frustrations which have marked my teaching in Women's Studies over the last few years.

But what struck me as well about this experience was the salience of translation in its most profound and structuring form. The assumption that the common project of feminism implied a common language or even common 'cultural literacy' was certainly not reinforced by this event. Rather we were plunged, in both productive and unproductive ways, into those incommensurabilities which are at the heart of the translation element present in all communication and which in postcolonial studies is perceived to be inherent in all articulations of 
cultural difference (Bhabha). But just as translations proceed in spite of the conceptual impossibilities of the task so might Women's Studies prevail in spite of its own impossibilities, as flagged for example by Wendy Brown's recent paper (Brown). Was it possible to conceive of trying to translate the cultural differences permeating global feminisms or to find a kind of common cultural literacy for a Women's Studies prepared to engage both with international feminisms and its own incommensurabilities?

I have taught Women's Studies in both Australia and Canada and have been involved in it since the late seventies, those heady early days which we later came to characterize rather more severely (and interrogatively) as the institutionalization and professionalization of Women's Studies. I find myself both reluctant and impelled to analyze the malaise which appears to have descended on the area at least in some parts of the world (Clark et al.; Stanley). It is difficult at times to disentangle what is particular to Women's Studies and to what extent we are dealing with the implications of university corporatisation (Evans; Threadgold) which has profoundly impacted on the Humanities and Social Sciences in general (Nussbaum). The appearance of special issues of relevant journals (differences; Atlantis etc) or anthologies such as Knowing Feminisms (Stanley), Anti-Feminism in the Academy (Clark et al.), Generations (Looser \& Kaplan) help us focus on the problems specific to Women's Studies.

\section{Restructuring: marginality as institutional advantage}

There is no doubt that we are in the midst of a huge restructuring of knowledge which questions the monopoly universities have traditionally enjoyed as privileged purveyors of knowledge and within this Women's Studies has things both to offer and to learn. What it has to offer is, to my mind, particularly related to interdisciplinarity - a way of re-organizing knowledge which is being acclaimed (sometimes for the wrong cost-cutting reasons) by university administrators 
everywhere. Women's Studies has the kind of track-record in interdisciplinarity (in all its permutations) that can offer cautions as well as insights. Paradoxically the precarious institutional history of much Women's Studies (see for example, Threadgold) could turn out to be its strength. Being marginal also means that one can respond more quickly as well as having less to lose by risking greater pedagogical experimentation. I think it is true that for a while now Women's Studies has represented in various ways a continuing experiment in interdisciplinarity as increasingly, for good and bad reasons, the interdisciplinary model is being explored by universities. Women's Studies is able to offer a tradition of experimentation in interdisciplinarity ranging from curriculum design, to pedagogical principles, to team teaching or, at least, to course articulation. This does not always mean that Women's Studies has been able to pursue these experiments systematically or to theorize them clearly but like cultural studies, for example, one can point to its grappling with interdisciplinarity in ways that traditional disciplines have found more difficult to pursue. In some ways I feel, at least from the programs with which I have been associated, that we in Women's Studies need to learn more about integrated interdisciplinarity, that is, have ourselves been guilty at times of taking it for granted merely because we had assumed we had the common focus of women. Much of what I've experienced has been a putting of disciplines side by side in a multidisciplinary way rather than working for an integrated model. Indeed, one can support a non-integrated model so long as the mix of courses and methods is overtly addressed rather than simply allowed to exist in haphazard fashion with no guidance for students. And, as I elaborate below, both models involve us in the task of translations between the disciplines. Having taken part in many interdisciplinary projects one learns very quickly that concepts as well as terminology do not mean the same things across the disciplines. For example: what counts as evidence in sociology as distinct from literary studies? What is meant 
by politics? What is assumed about identity as distinct from a more dispersed poststructuralist subjectivity? To name a few.

Initially, for the first two decades, one could describe Women's Studies relatively unproblematically as a field which functioned as a critique of masculinist knowledge structures. ${ }^{2}$ This is where it gained its impetus and gradually a kind of idiosyncratic legitimacy. However now, as many have pointed out, when we are faced with declining numbers in both students and faculty we are also confronted with the need to rethink the curriculum. For me this was clearly delineated as a problem when I recently transposed a feminist theory in the humanities course which I had been teaching for several years in Women's Studies to my cross-appointed field of English. The modifications I needed to make and the assumptions about what I expected my students to know in each case clarified some dilemmas for me. On the one hand it reminded me that feminist work is vigorously being generated within the disciplines but that this work does not always have a self-evident relationship with programs in Women's Studies. The feminist work within disciplinary areas is intrinsically embedded in a larger framework of accreditation and professionalization associated with specific disciplinary training. And it is not as though this ceases to function, albeit in a semi-conscious manner, within Women's Studies courses themselves. Because many programs use cross-appointed or cross-listed faculty and courses, in part as a matter of principle and otherwise due to economic efficiency, there are few programs staffed entirely by those trained only through Women's Studies itself. In other words, the skills which faculty bring to the programs are thoroughly informed by their own disciplinary training. This can be at odds with the rhetoric that Women's Studies offers genuine interdisciplinarity. Often the reality is a smorgasboard which is structured along the disciplinary lines familiar to the faculty teaching in the program. In practice this can, for example, lead to a split between humanities and social sciences and certainly to a further distancing from the sciences, medicine etc. In other words, because of the institutional history of 
Women's Studies as primarily occurring in Faculties of Humanities and the Social Sciences as well as being subjected to a legacy of underfunding and marginalization there has often not been either the time or the resources to fully articulate an interdisciplinarity which has been thought through and subjected to processes of translation in terms of finding a common language of pedagogy.

The question in relation to Women's Studies arises as to what exactly we are therefore trying to achieve in such programs. Echoing Wendy Brown, what do we want our students to know? It is clear that we cannot simply or exclusively remain with the concept of Women's Studies as the place from which to critique the rest. While this may bea continuing element and a legacy of Women's Studies in its first stage, it cannot remain as its primary identification. This dilemma is addressed by graduate student Renea Henry when she states: "There is the question of which kind of training a student receives. What are you prepared to teach? What have you learned? If you turn these programs into a sort of center to critique power, what is it that you are prepared to address substantively and how?" (Cook, Henry and Scott 142). What kind of 'disciplining' are we providing and what therefore authorizes us; what legitimizes our pedagogy? One assumption is that we are training agents for social change, but if this remains at an inchoate level it invites the kind of charge which leads longtime opponents to accuse Women's Studies of simply being staffed by ideologues who contaminate the objectivity of university-generated knowledge. Amongst ourselves the rhetoric around the idea that we are engendering a kind of activism is often not thought through in terms of what has sometimes been described as the uneasy history of the relationship between politics and theory or, more simply, politics and intellectual knowledge.

Capitalizing on my good fortune in having taught in several different contexts, I would like to introduce some Canadian reflections at this point. Published a decade ago in 1990, a special issue of the Canadian Women's Studies journal Atlantis dealt with the findings of 
a very interesting study called the Canadian Women's Studies Project. As described by one of the co-ordinators Margaret Eichler, it comprised widespread interviews with women teaching in Women's Studies across the country and charted how and by whom such programs were instituted. Eichler herself examines the relationship between Women's Studies and feminism, calling the first a subject area and the second an approach. She argues that we cannot take the relations between the two for granted just as, increasingly, we cannot make the two synonymous. It is therefore important that we label our work feminist in order to signal its distinction from Women's Studies courses which do not have a feminist approach (Eichler). ${ }^{3}$ In the same issue Rhonda Lenton looks at the relationship between academic Women's Studies and the wider women's community and concludes that the incorporation of Women's Studies within the academy has rendered it more conservative, particularly amongst younger scholars. She concludes: "If feminist scholars are to retain a critical position toward the discipline and if they are to provide leadership within the feminist movement, they will need to maintain ties with political activists outside of academia" (Lenton 67). While on the one hand statements such as this one allow us to point to Women's Studies as a model to offer the restructuring agents in the university at large who are looking for ways to bring the community and university together (for reasons of sheer survival) we also need to consider carefully our own ties with community groups and to think about this in relation to the academic project in general. Does entry into the academy automatically uncouple Women's Studies from a supposedly self-evident feminist politics? Why is theoretical and intellectual work so often perceived as non- or a-political? The urgency is compounded by another institutional 'success story' for Women's Studies which relates to the growth of practicum programs. Part of the call for accountability which has been linked with the increasing intervention of local political concerns into the funding and business of universities has resulted in greater attempts to bring the community and university into proximity with each other. Women's Studies has 
had a long record, once again, in doing this through its ties to the women's movement. While academic feminism has often been accused of severing this link (as exemplified by Lenton's statement above) it is certainly the case that Women's Studies programs have generally preserved a much closer liaison with varieties of community women's groups than have other disciplines in the university. This has now been consolidated into practicum programs. ${ }^{4}$ In Australia it has also taken the form of policy work and there is a long tradition there of universities providing consultancy bases for policy work for government agencies (Yeatman 1990, 1998). But, once again, the relationship is an uneasy one and needs to be carefully monitored so that it does not, amongst other implications, help support the growing perception that university knowledge and training are only of value insofar as they prove their immediate and instrumentalist 'relevance' to contemporary community issues or that the practicum is a guarantee of activism which otherwise does not exist within the university boundaries.

One way to complicate this tendency is that it would be very helpful to pool our knowledge about the university itself as a site for feminist politics. My first four years in Canada were acutely marked by two quite separate and extremely painful cases of charges of sexual and racial harassment occurring, oddly enough, in departments of Political Science at the two universities where I was teaching (Chilly Collective; Fekete; Emberley; Marchak). I learnt a great deal from both examples about on the one hand the litigious nature of North American society and as well about the limits of tolerance for gender and race concerns within universities. But one thing both these experiences accomplished, as do the recent writings of Jane Gallop, was to politicize staff and students and to show without doubt that the university itself was a charged political space (Gallop 1995, 1997, 1999; Gallop and Francis).

A further problem is one which has been tackled in the theorization of Women's Studies for some decades and concerns the differences within and amongst feminists which have been described by many as 
a fragmentation into feminists of difference (those who query the definitions of women and certainly of the commonality initially attributed to women's experience) and others who feel we cannot (politically) afford such interrogations. For example, if we look at what has been dubbed the 'third wave' of feminism in North America its prime concern with race and sexuality involves, amongst other things, an interrogation of orthodoxies which are also perceived to reside within mainstream feminism. In the US, Devoney Looser speaks as a third wave feminist, whom she describes as "the new feminisms and feminists emerging in the late 1980s and 1990s, many of whom purport to interrogate race, nation, and sexuality more thoroughly than did the second wave, and many of who are skeptical about the unity of the category 'women' " (Looser 38). She also contends that in the writing of second wave feminists her generation are often perceived as the mongrel strays betraying the ideals of the 'purebreds' (Looser 37). This characterization also seems to haunt the exchange between Susan Gubar and Robyn Wiegman in relatively recent issues of Critical Inquiry (Gubar; Wiegman). It might also be useful to bear in mind Canadian feminist Jill Vickers' caution that "there are currently two major barriers impeding our progress toward the goal of effective women-centered knowledge in the social sciences: first, our difficulty in dealing with difference as a theoretical and research problem and second, the constant lure of subjectivism and radical individualism which comes from feminism's privileging of individual experience and our tendency to reject authority (even feminist authority) as the basis for knowledge" (Vickers 222). One of the most pernicious directions taken by this subjectivism is that of identity politics, a development which has paralyzed many women's projects (Elam). How might one locate or construct intellectual and pedagogical interventions that avoid the general reductionism of identity politics?

The debates around identity politics have a particular resonance within global feminism although their detailed meanings are often dependent on local contexts. The phenomenon might be traced to the 
'consciousness-raising' tactics which are historically associated with second-wave feminism and led from the articulation of women's collective differences to the delineation of other group differences. But, increasingly, these differences have congealed into imprisoning essentialisms which are often perceived as obscuring more than they illuminate, of occluding intra-group differences and preventing the recognition of the realities of 'intersectional identities' (Crenshaw 333). Martha Minow has argued that identity politics "may freeze people in pain and also fuel their dependence on their own victim status as a source of meaning" (Minow 54). She goes on to state that: "Identity politics tends to locate the problem in the identity group rather than the social relations that produce identity groupings" (56). Jodi Dean contends that: "The articulation of particular identities has led to the rigidification of these very identities. At the legislative level, this rigidification appears as the reinforcement of minority status with its negative connotations of inferiority" (Dean 5). In the context of the struggle by 'women of colour' to asserts their own politics of difference, Analouise Keating cautions "not to abandon all references to personal experiences but rather to take experientially based knowledge claims even further by redefining identity" (36). Keating draws on Chela Sandoval's concept of 'differential consciousness' and on Homi Bhabha's notion of 'ambivalent identification' as a way to move to such new definitions of identity. At its worst, identity politics are invoked as part of individualised experience and prevent the kind of theoretical analysis that is at the very heart of the academic enterprise. Such anti-intellectualism has led feminists such as Wendy Brown to identify a serious split between academic feminism functioning within the disciplines and a version of Women's Studies which "consolidates itself in the remains, impoverished by the lack of challenges from within" (Brown 84).

Without in any way wishing to invoke the specter of identity politics in any essentialist manner, what is not always identified to the same extent in these inquiries is the changing nature of Women's Studies students themselves. In my own recent experience there have been some disturbing manifestations registered in the curricular translation 
from Women's Studies to English which I mentioned above. While some of my Women's Studies students were reluctant to do the historical and theoretical work which underpinned our exploration of representation in a range of texts, some of the English honors students were comparably uncomfortable in talking about some of the political implications of these representations and their embeddedness within social relations. One explanation resides in the general assumption that if Women's Studies is a training ground for activism then there is not much patience among students either for historical inquiry or for epistemological questioning. Activism remains more comfortable with categorical certainties preferably confined to the here and now. Nor is there, necessarily, much curiosity about activism elsewhere in the globe. At its worst this manifests itself in the profoundly chauvinist manner of the kind alluded to by Shirley Yee in her statement that "foregrounding any understanding of 'women' from a US-based trajectory is inherently problematic when attempting to internationalize 'Women's Studies' “ (Yee 57-58).

This dilemma is complicated by the fact that differences are also becoming more obvious in the changing nature of the student body itself in many of the countries which have been offering Women's Studies. The diversification in terms of ethnicity, class, sexuality has not necessarily been fully addressed by either the curriculum or pedagogy in more general terms. My own interests relate particularly to postcolonial issues, that is, to ethnicity and cultural differences. Teaching in a university system in Australia for several decades where multiculturalism was minimally recognized (particularly in relation to cultural issues) as a field of research or as worthy of archival work it was hardly surprising that the various ethnic affiliations of our increasingly multicultural student body were not being adequately addressed (Gunew 1994). Having taught in Canada for the last six years I have found a far greater commitment to acknowledging the cultural diversity of the national culture but this has not necessarily flowed into the local specificities of the curriculum (Miki, Philip, Bannerji). Universities have traditionally been concerned with the eternal verities 
and with the continuities of knowledge construction. The implications of a changing student body were at best perceived as ephemera which required the compensatory stability of pedagogical uniformity. The fact that a large percentage of the student body where I teach now have affiliations (over several generations) to a range of Asian cultures is only very gradually being recognized in the curriculum in general. Given this situation the complexities of devising a common cultural literacy for feminism and Women's Studies is profoundly challenging.

\section{Translation: globalization translated into internationalization}

In over-simplified terms globalization in this paper refers to the dissemination of communication technology and attendant economic rationalization whereas internationalization conveys the ways in which global issues are interpreted at a local level. Outside North America, and even within if we are taking a Canadian perspective, globalization often translates into US-centrism, that is, the charge that US culture is colonizing the world. What is left out of this glib binarism are the multiple differences within the US where there are indeed local interpretations of and oppositions to globalism not unlike those which proliferate outside the US. To take up these tactics in more detail, recent statements in the various collections I mentioned earlier as registering the malaise within Women's Studies and feminist projects are rife with warnings that key terms do not mean the same thing globally as they do locally. Global feminism as currently practiced in North America, for example, tends to naturalize rather than deconstruct terms such as third and first world (Narain; Yee 59). If we were to imagine that the intersection of two versions of feminism were comparable to what happens when texts in two languages intersect then Anna Loewenhaupt Tsing's concept of 'faithless translation' is an enabling possibility. Drawing on contemporary translation theory she suggests that all translations are inherently faithless in that something new is created in the slippage between languages and texts. It is this slippage which 
needs to be explored when varieties of feminism and Women's Studies meet. But what does this mean in concrete terms? Tsing gives three examples informed by her postcolonial perspective:

First, instead of tracing a Western history of social thought, we can trace the moves in which lists of Western thinkers appear to be History. Second, instead of following Western originals across non-Western cultural transformations, we can follow the narrative contests through which foci of cultural difference are identified. Third, instead of debating the truth of Western-defined universals, we can debate the politics of their strategic and rhetorical use across the globe. (Tsing 254)

What I note in the above is that there is a somewhat easy invocation of the 'West' or 'Europe' in much postcolonial theorizing and that this too is a category which needs to be deconstructed. This unease is also registered, for example, by Rosi Braidotti in an essay in the same volume when she calls for the need to "problematize and to historicize the question of what, if anything, constitutes European" (Braidotti 356). Echoing the ground-breaking work of Donna Haraway amongst others, Braidotti offers a timely reminder of the need to consider all knowledge, including feminist knowledge as 'situated practices' (Braidotti 357). In very practical terms Braidotti's piece goes on to delineate Women's Studies in the European Union where she gives information concerning the Erasmus project of exchanging students and faculty across the European Community. These kinds of intra- and inter-institutional collaborations have been part of the history of Women's Studies programs in many places. The new direction we are seeing now are to forge joint programs with Women's Studies teams in Asia and SouthEast Asia of the kind that Braidotti identifies within Europe. These moves are facilitated by the new technologies which enable teams to collaborate across the globe to produce course materials: a clear example of an homogenizing global tool being transformed by local forces to 
create a truly diversified internationalism. Such collaborations will help dispel the prevailing notion that North American feminism is a homogeneous colonizing force and will help disseminate the recognition that there are many differing versions and differing politics within these supposedly unified metropolitan centers. In my own work it has become very clear to me that not only are we enmeshed in the phenomenon of travelling theory where theories metamorphose in response to the local circumstances in which they are embedded but that terms we think of as being global or universal have very particular local and national meanings. In the wake of the break-up of the Second World and the development of what has been termed globalization or the restructuring of the 'Third World' we now have very different interactions between various versions of what counts as feminist and how that informs Women's Studies curricula and pedagogical practices. This is something I glimpsed at the Budapest conference.

But let us now move to some concrete example of the kinds of imbrications and 'faithless translations' which some of us have attempted in recent pedagogical enterprises as a way of bringing feminism and Women's Studies into challenging proximity. One such project with graduate students and colleagues concerned our examining a number of texts, written and cinematic, dealing with the intersections of women, food and ethnicity. The digestion of food is the underlying metaphor for social assimilation and so it is singularly apt to focus on the domain of food to bring to the fore the unassimilated incommensurabilities which abound in the relations between women and food. For example, there is Canadian writer Hiromi Goto's A Chorus of Mushrooms in which three generations of women in a Japanese Canadian family direct their struggles with identity through language and food. To those of us familiar with Kristeva's work it was clear that whenever these two elements come together cannibalism, symbolically at least, lurks in the shadows. Drawing on the work of Kristeva and Maud Ellmann concerning the war between language and food within the subject, we also speculated about the ways this might have implications for the practices of citation and quotation in academic texts 
and, in particular, for textual relations in translation. The examples below constitute some attempts to make more tangible what I have rather abstractly been trying to posit as the productive possibilities which may occur in an encounter between some general theories relating to cultural difference when they meet very specific texts which are at a tangent to global feminism when it is conceived in a hegemonic, universalistic manner. These speculations are organized around the trope of cannibalism chosen because its charged implications capture both the fascination and repulsion involved in registering the contact processes of two individuals or groups. I am not the first to consider the tactic of using this most shocking model of human interaction as a way of 'fighting back' to imperialism, colonialism or other hegemonic forces, as the example of the Brazilian modernists cited below makes clear. I am merely 'translating' these tactics into ones which might be a useful way for feminist theory to 'make strange' the current paralysis in Women's Studies in relation to identity, difference and critique.

\section{Anthropophagy: towards a theory of (faithless) translation}

In the variegated global domain of multicultural studies one of the few consistently benign ways to refer to diversity is via ethnic cuisines, particularly within the increasingly anxious space of the nation. But what really is being consumed when multicultural food is celebrated? I would suggest that what may be at play here is assimilating the multicultural other, particularly as this is exemplified in texts (written and cinematic) by minority women. Recent anthologies such as Hungry for You: From Cannibalism to Seduction. A Book of Food (Smith) or Slavenka Drakulic's The Taste of a Man exemplify the ways in which cannibalism is used to figure the pleasures of love, consuming the other as the ultimate expression of sexual (and other) consummations. At the same time the rise in texts dealing with the experience of anorexia/ bulimia also deal with self-consumption (the ultimate form of narcissism). A plethora of texts dealing with women's manipulation of 
food as metaphor for their roles in the family, the community and the nation have been appearing over the last decade.

In a recent collection enticingly titled Post-colonial Translation the editors are particularly impressed with the trope of cannibalism developed by one of the authors as an apt encapsulation of the power differentials inherent in all translation events (Bassnett and Trivedi). Traditionally, the 'original' text is given mystic powers but what really is the original? This has long been a point of contention in postmodernist debates in particular. ${ }^{5}$ The critic Elsie Vieira explores the work of the Brazilian translator Haroldo de Campos in the context of the notorious Brazilian modernist manifesto which structured itself according to anthropophagy. Drawing on the original Tupa Indians' supposed penchant for cannibalism it intersects this with the Jesuit mission of conversion structured in turn by the symbolic cannibalism of the Christian Mass (Vieira 98). Both traditions, those of the colonized and the colonizer, are thus brought together in the trope of cannibalism which elevates the former to the same symbolic and ethical level as the latter, or, at the very least shows that they are structurally connected.

\section{The cannibal looks and answers back}

In her recent book Fatimah Tobing Rony explores, as does her film On Cannibalism, the nature of ethnographic cinema and what she calls the 'third eye', a variant on W. E. Du Bois' double consciousness or Edward Said's 'contrapuntal' perspective. In other words, it is a way for those who are objectified by, in this case, the European ethnographic gaze to look back, to resist being turned into objects "without history, without writing, without civilization, without technology, without archives" (Rony 7). Rony sets up the three stages of ethnography beginning with i) Félix-Louis Regnault's ethnographic studies of time and motion in order to uncover a taxonomy of race through gesture, to ii) cinematographer Robert Flaherty's restaging of Inuit culture in Nanook of the North set within the framework of the teleological certainty that indigenous races would die out, to iii) King Kong which 
she sees as an ironic moment in ethnographic film. In her film, On Cannibalism, the narrator identifies with the 'bride of King Kong' which is used as a position from which to explore the 'other's' or 'cannibal's' knowing look back. In her exploration of what she calls 'fascinating cannibalism' she draws attention to the voyeuristic consumers of ethnography, of the bodies of the 'Savage' (Rony 10).

As the film illustrates, there is a long history of cannibalism within 'European' culture and, as the postcolonial critic Peter Hulme points out, "Cannibalism is - as practice or accusation - quite simply the mark of greatest imaginable cultural difference and therefore the greatest challenge to our categories of understanding" (Hulme20). Approaching these issues from a rather different perspective, Marina Warner's study of Western folklore No Go the Bogeyman is also replete with cannibalisitic motifs and suggests that what post-colonialists designate as cultural difference extends to, or perhaps begins with, sexual difference, a point of particular interest to feminist researchers. In European folklore cannibalism is mostly attached to relations between male figures and children and, according to Warner, women in Greek myth, for example, may kill their children but don't eat them (Warner 56). On the other hand, there is also the witch/bad mother figure who stalks more general folklore and who does indeed eat children (though not usually her own). Warner associates the devouring male figure, in turn, as representative of couvade, male envy of women's ability to give birth:

This cannibal motif conveys a threefold incorporation: sexual union by which a form of reciprocal devouring takes place, pregnancy, by which the womb encloses the growing child, and

paternity, which takes over the infant after birth in one way or

another. The metaphors are enchained, one to another - sex, obliteration, food - as language strains to convey the tension 


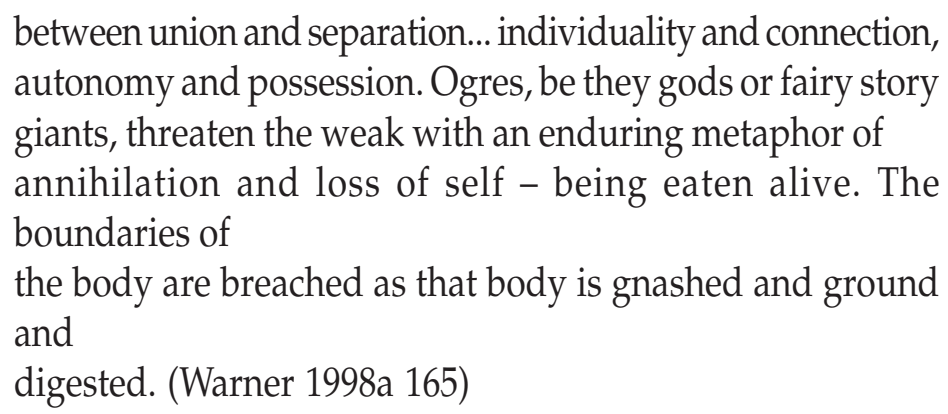

Warner considers the image of the bogeyman/ogre as an archetypal figure for male legitimacy and authority. In the eyes of the material historians the prevalence of the cannibal motif supposedly derives quite rationally from the many famines in European history but if one looks to psychoanalysis or the structuralism which ordered an earlier version of anthropology - the 'deep structures' in various ways - one possibly encounters another kind of logic at play.

In relation to Warner's work on folklore Peter Hulme states that: "Cannibalism here operates as family romance, its stories engaging with the fundamental enigmas of kinship: what is the relation between identity and origin?; how can doubleness of origin (from mother and father) be expressed?; how does biological origin convert into social relation?" (Hulme 33). But as in the case of the Brazilian translator referred to above, we too might speculate about the nature of origins, originals, progenitors. Slavenka Drakulic's powerful (and in some ways comic) novel The Taste of a Man enables us to pursue some of these implications. Ostensibly this text celebrates a familiar cannibalistic motif in relation to incorporation as sexual union: the kind where the two beings are so caught up in each other that they form a whole, a closed circuit which is profoundly anti-social and which can only end in suicide or madness (one thinks here as well of the Japanese cinematographer Oshima's famous film In the Realm of the Senses) or of Gloria Anzaldúa's poem "The Cannibal's Canción" (Anzaldúa).

The book begins with a scenario of Kristevan abjection with the narrator pondering the difficulties of cleaning up after a murder. She 
recalls her mother with her legacy of obsessive cleanliness and the maintenance of boundaries. In contrast, we are quickly presented with a rationale for the events recounted in flashback. The female narrator refers to her desire to merge with her lover, to erase all boundaries - the only solution to the fact that he has to return to his family, eventually. Coming from two different cultures they cannot communicate through language: "Had I been able to reach him through words ... our relationship probably would have ended differently" (Drakulic 41). Thus because they cannot converse in more prosaic manner they connect primarily through their bodies - through sex and food. In her brilliant study of self-starvation Maud Ellmann, taking her departure from Freud, considers the contest between food and words, "words and food are locked in eternal rivalry" (Ellmann 46) in that both attempt to occupy or colonise the same corporeal space - the mouth. We encounter the narrator after she has killed her partner. She feels already that he animates her from inside her body (Drakulic 7). She recalls their first meal together after they had sex for the first time. Already then the food becomes synonymous with their bodies: "We pounced voraciously on the food and then our hunger for food mixed with our hunger for each other... I know now that I should have recognized that first shared meal as the true desire to feed ourselves to each other and thus become one. Food was part of our intimacy, our union, as important as touching itself" (Drakulic 35-6). At one stage she makes the kind of soup which signals commensality, the bringing of people together into family and community by women in particular (Drakulic 40). But this is a rare moment which ultimately functions to accentuate their inability to be part of the social world around them.

Meanwhile, the surrounding world begins to send her hermetic signs of their inescapable destiny. A poem by George Hebert signals for her an association of love with eating the beloved (Drakulic 84). José, the lover, dreams of eating his own sister (Drakulic 166-67). Later, after the narrator has fed him a drink laced with sleeping pills and he lies dying, she is overcome by an immense hunger which drives her out into the street in search of sustenance. She returns and after killing 
him begins to eat him. The initial spiritual dimension of the ritual is overtaken by a physically voracious and bestial hunger: "I glanced in the mirror above the sink. My mouth was bloody like an open wound, or like the snout of a beast poking into a carcass" (Drakulic 186). At various points she compares her hunger to pregnancy; the notion of having to "eat for two" (Drakulic 176), a common euphemism for pregnancy, takes on a demonic meaning. She tells the reader that a normal pregnancy would have produced a new being, only partly José (Drakulic 180); it is precisely the establishment of the social that she rejects. So on the face of it this text deals with cannibalistic incorporation in terms of sexual union.

However, a further dimension of the text places it in the context of the postcolonial cannibal looking back and identifying the primacy of European cannibalism, as in Fatimah Rony's work. ${ }^{6}$ The lover, José, turns out to be an academic studying cannibalism and the text is littered with knowing references to the literature. Moreover, José is Brazilian and the shadow of his Indian ancestors lurks, in feminized manner, within his persona.

Sometimes, when I looked at him for a long time, I would see another colour burning under his skin. His light complexion would seem a mere illusion then; his full lips, the black glint in his eyes, the small nose and wide nostrils, the slanting forehead would give him away. From beneath the pale skin would emerge the well-defined shadow of an Indian woman, his otherness which so fascinated me. Not only was he a separate being, which was painful enough, but he was doubly other - because of language, and because of the world he came from, a world about which I knew nothing. (Drakulic 44; see also 69)

As well, there is quite possibly a knowing wink to the Brazilian manifesto on modernism which, as mentioned, was symbolically 
structured around 'anthropophagy'. According to Sérgio Bellei, this involved the following tropes, "the stomach without ideas, ready to devour everything, already points to anthropophagy as a metaphor for the cosmopolitan enterprise of absorbing both foreign and native cultures as the means to construct a hybrid and unique Brazilian cultural identity ... legitimating anthropophagy by transforming the taboo of the primeval father's parricide (the father being in this case the European colonizer) into the acceptable eating (by the colonized) of the totemized animal that symbolically replaced the primeval father" (Bellei 91-93). Before she returns to Poland the narrator visits a church from which she emerges reborn (Drakulic 206). Like many European colonizers before her she is able to purge her guilt through the rituals of the Christian church. José is better off within her. His surviving relic, the head which maintained his individuality after his body had been dismembered and disposed of, has decayed into an inhuman mess. ${ }^{7}$ The narrator returns to Europe, sheathing the essential José within her own body, another demonic inversion of pregnancy, while bearing a Braun food mixer which she had exchanged for the electric saw that had enabled her to dismember his body. In sum, a brilliant satire on the cannibalistic motif but casting as well a sly eye on certain feminist orthodoxies particularly those connected with the privileging of essentialist identity politics. The 'faithless translation' inherent in the trope of cannibalism may well help Women's Studies develop a common literacy which moves us beyond the recent paralyzing battles around identity politics. ${ }^{8}$

To speak about Drakulic's text in the 'first' world might be interpreted as drawing parallels between Western European's colonialism towards both South America and, latterly, Eastern Europe. To speak about it in Eastern Europe is to invite a reading which has Eastern Europe speak back both to its Western cousin and to the US globalism mentioned earlier. It also involves the wry re-staging of a familiar erotic scenario in which the victim is male and the aggressor female. A reversal of gender-based orthodoxies takes place which might 
provide useful tools for estrangement when teaching these categories in Women's Studies. Using the symbolic framework of anthropophagy and this text as a case study suggests that these kinds of reversals and shock tactics might be required to stop the implosion within certain forms of Women's Studies where members of the community turn upon and silence each other in ever narrowing circles as to whose authority should be counted, whose voice heard, in designating victims and systems of oppression. In such instances the traditional categories of analysis: class, gender, race function in increasingly universalised and un-nuanced ways to prevent the very notion of porous cross-cultural, internationally sensitive collaborations which to many of us are the exciting future of Women's Studies. To maintain that model a feminist theory ready at all times to question its own terminology and methodology, its own basis for authority, remains a given. In Budapest there was a great deal of questioning but there were also many silences and many stereotypic notions of how our various feminist enterprises moved in the world. The image of a cannibal, that most abject of humans (indeed to designate someone a cannibal is to mark them as abject, beyond the pale) looking and speaking back to the taxonomists, the legislators, those in the know could well function as a galvanising icon (or mascot) for our future projects and our potential attainment of common cultural literacies. 


\section{Notes}

1 See Salecl, 1994. Zizek is so prolific that it is difficult to choose just a few texts but see Zizek 1984.

2 This was exemplified in the two anthologies of feminist theory I edited for Routledge. See Gunew 1990;1991.

3 Her comments have some resonance with Brown's comments almost a decade later.

4 See the section "Women's Studies in Focus: Field-Based Learning in the Practicum Course," Atlantis 221, Fall/Winter 1997, 109-134.

5 Jorge Luis Borges' story "Pierre Menard, Author of the Quixote" is often invoked as paradigmatic text in these debates.

6 A particularly succinct favourite of mine is Witi Ihimaera's poem "Dinner with the Cannibal," SPAN vol. 36.no.1, 1993, pp. 154-5.

7 It is difficult not to read this as an allusion to the ending of Stendhal's Le Rouge et le Noire, another famous example of amour folle.

8 Many feminists have written on these battles but see Elam and Gunew (2000).

\section{Works cited}

Bannerji, Himani. "On the Dark Side of the Nation: Politics of Multiculturalism and the State of 'Canada'," Journal of Canadian Studies, Autumn, 31.3 (1996). 103128.

Bassnett, Susan and Harish Trivedi. "Introduction: of colonies, cannibals and vernaculars," in S. Bassnett and H. Trivedi (eds.), Post-Colonial Translation: Theory and Practice, NY: Routledge, 1999. 1-18.

Bellei, Sérgio Luiz Prado "Brazilian Anthropophagy revisited", in Francis Barker, Peter Hulme, Margaret Iverson (eds.) Cannibalism and the Colonial World. Cambridge: Cambridge UP, 1998. 87-109. 
Bhabha, Homi. The Location of Culture, London: Routledge, 1994.

Borges, Jorge L. "Pierre Menard, Author of the Quixote", in Labyrinths. Harmondsworth: Penguin, 1971. 62-71.

Braidotti, Rosi "Uneasy Transitions: Women's Studies in the European Union," in Joan Scott, Cora Kaplan, Debra Keates (eds.) Transitions, Environments: Feminisms in International Politics, N.Y.: Routledge, 1997.

Brown, Wendy. "The Impossibility of Women's Studies", in Differences (Women's Studies on the Edge), 9. 5, Fall (1997). 79-101.

Chilly Collective (eds.) Breaking Anonymity: The Chilly Climate for Women Faculty. Waterloo: Wilfred Laurier P, 1995.

Clark, Vèvè, Shirley Nelson Garner, Margaret Higonnet, and Ketu H. Katrak (eds.) Antifeminism in the Academy, NY: Routledge, 1996.

Cook, Kathryn, Renea Henry with Joan Scott. "The Edge Interview", in Differences (Women's Studies on the Edge), 9. 5, Fall 1997. 132-155.

Crenshaw, Kimberlé. "Mapping the Margins: Intersectionality, Identity Politics, and Violence Against Women of Color", in D. Danielsen and K. Engle (eds.) After Identity: A Reader in Law and Culture, N. Y.: Routledge, 1995. 332-354.

Dean, Jodi. Solidarity of Strangers: Feminism After Identity Politics, Berkeley: University of California Press, 1996.

Drakulic, Slavenka The Taste of a Man (trans. C. Zoric) London: Abacus, 1996.

Eichler, Margrit "What's in a Name? Women's Studies or Feminist Studies?" in Atlantis: A Women's Studies Journal/Revue d'études sur la femme, (Special Issue: Report of the Canadian Women's Studies Project), 16.1, Fall (1990). 40-56.

Elam, Diane. "Sister Are Doing It to Themselves", in Looser, Devoney and E. Ann Kaplan (eds.) Generations: Academic Feminists in Dialogue, Minneapolis: U of Minnesota P, 1997. 55-68.

Ellmann, Maud. The Hunger Artists: Starving, Writing, and Imprisonment. Cambridge, Mass.: Harvard UP, 1993. 
Emberley, Pter C. Zero Tolerance: Hot Button Politics in Canada's Universities, Toronto: Penguin B. 1996.

Evans, Mary. "Negotiating the Frontier: Women and Resistance in the Contemporary Academy", in L. Stanley (ed) Knowing Feminisms: On Academic Borders, Territories and Tribes, London: Sage, 1997. 46-57.

Fekete, John. Moral Panic: Biopolitics Rising, Montreal: Robert Davies. 1994

Gallop, Jane (ed). Pedagogy: The Question of Impersonation, Bloomington: Indiana UP, 1995.

_.Feminist Accused of Sexual Harassment, Durham: Duke UP, 1997. .and Elizabeth Francis. "Talking Across," in Looser, Devoney and E. Ann Kaplan (eds.) Generations: Academic Feminists in Dialogue, Minneapolis: U of Minnesota P, 1997. 103-131.

."Resisting Reasonableness", Critical Inquiry, 25. 3, Spring (1999). 599-609.

Gubar, Susan. "What Ails Feminist Criticism?" Critical Inquiry, 24. 4, Spring (1998). 878-902.

Goto, Hiromi. Chorus of Mushrooms. Edmonton: NeWest P., 1994.

Gunew, Sneja (ed.) Feminist Knowledge as Critique and Construct, London: Routledge, 1990.

.(ed.) A Reader in Feminist Knowledge, London: Routledge, 1991.

.Framing Marginality: Multicultural Literary Studies, Melbourne: Melbourne UP, 1994.

.(2000) "Operatic Karaoke and The Pitfalls of Identity Politics: A Translated Performance", in S. Ahmed et al. (eds.) Transformations: Thinking Through Feminisms, London: Routledge.

Hulme, Peter, "Introduction: The Cannibal Scene", in Barker, Francis, Peter Hulme, Margaret Iverson (eds.) Cannibalism and the Colonial World. Cambridge:Cambridge UP, 1998. 1-38. 
Keating, Annalouise. "(De)Centering the Margins? Identity Politics and Tactical (Re)Naming", in S. K. Stanley (ed.) Other Sisterhoods: Literary Theory and U.S. Women of Color, Urbana: University of Illinois P, 1998. 23-43.

Kristeva, Julia. Powers of Horror: An Essay on Abjection, trans. Leon S. Roudiez. NY: Columbia UP, 1982.

Leighton, Rhonda "Academic Feminists and the Women's Movement in Canada: Continuity or Discontinuity," Atlantis: A Women's Studies Journal/Revue d'études sur la femme, (Special Issue: Report of the Canadian Women's Studies Project), 16.1, Fall (1990) 57-68.

Looser, Devoney. "Gen X Feminists? Youthism, Careerism, and the Third Wave," in Looser, Devoney and E. Ann Kaplan (eds.) Generations: Academic Feminists in Dialogue, Minneapolis: U of Minnesota P, 1997. 31-54.

Marchak, M. Patricia. Racism, Sexism and the University: The Political Science Affair at the University of British Columbia, Montreal: McGill UP, 1996.

Miki, Roy. Broken Entries: Race, Subjectivity, Writing: Essays, Mercury P, 1998.

Minnow, Martha. Not only for Myself: Identity, Politics, and the Law, N.Y.: The New P, 1997.

Narain, Mona. "Shifting Locations: Third World Feminists and Institutional Aporias", in Looser, Devoney and E. Ann Kaplan (eds.) Generations: Academic Feminists in Dialogue, Minneapolis: U of Minnesota P, 1997, 151-164.

Nussbaum, Martha C. Cultivating Humanity: A Classical Defense of Reform in Liberal Education, Cambridge, Mass.: Harvard UP, 1997.

Philip, Marlene Nourbese. Frontiers: Selected Essays and Writing on Racism and Culture 1984-1992. Stratford, Ontario: Mercury Press, 1992.

. "Signifying: Why the Media have Fawned over Bissoondath's Selling Illusions." Border/Lines Magazine, 36 (1995). 4-11.

Rony, Fatimah Tobing The Third Eye: Race, Cinema, and Ethnographic Spectacle Durham: Duke UP, 1996. 
.On Cannibalism, 6 min. film, 1995.

Smith, Joan (ed.) Hungry For You: From Cannibalism to Seduction. A Book of Food. London: Chatto \& Windus, 1996.

Stanley, Liz (ed). Knowing Feminisms: On Academic Borders, Territories and Tribes, London: Sage, 1997.

Salecl, Renata. The Spoils of Freedom: Psychoanalysis and Feminism After the Fall of Socialism, NY: Routledge, 1994.

Threadgold, Terry. "Gender Studies and Women's Studies", in Reference Group for the Australian Academy of the Humanities (ed.), Knowing Ourselves and Ohters: The Humanities in Australia into the 21st Century, vol. 2 Discipline Surveys, Canberra: Commonwealth of Australia, 1998.127-138.

Tsing, Anna Loewenhaupt. "Transitions as Translations”, in Scott, Joan, Cora Kaplan, Debra Keates (eds.) Transitions, Environments: Feminisms in International Politics, N.Y.: Routledge, 1997. 253-272.

Vickers, Jill "Difficult Choices: The Knowledge Strategies of Feminist Social Science and the Knowledge Needs of Women's Movements," in Parameswaran, Uma (ed), Quilting a New Canon: Stitching Women's Words, Toronto: Sister Vision Press, 1996. 221-240.

Vieira, Else Ribeiro Pires. " Liberating Calibans: readings of Antropofagia and Haroldo de Campos' poetics of transcreation" in S. Bassnett and H. Trivedi (eds.), PostColonial Translation: Theory and Practice, London and NY: Routledge, 1999. 95113.

Marina Warner. No Go the Bogeyman: Scaring, Lulling and Making Mock. NY: Farrar, Straus and Giroux, 1998.

."Fee fi fo fum: the child in the jaws of the story," in Barker, Francis, Peter Hulme, Margaret Iverson (eds.) Cannibalism and the Colonial World. Cambridge: Cambridge UP, 1998a. 158-182.

Wiegman, Robyn. "What Ails Feminist Criticism? A Second Opinion", Critical Inquiry, 25. 2 Winter (1999). 362-379. 


\section{Sneja Gunew}

Yeatman, Anna. Bureaucrats,Femocrats, Technocrats: Essays on the Contemporary Australian State, Sydney: Allen \& Unwin, 1990.

. (ed.). Activism and the Policy Process, Sydney: Allen \& Unwin, 1998.

Yee, Shirley. "The 'Women' in Women's Studies", in Differences (Women's Studies on the Edge). 9. 5 Fall (1997). 46-64.

Zizek, Slavoj. The Sublime Object of Ideology, London \& NY: Verso, 1989.

.The Metastasis of Enjoyment: Six Essays on Women and Causality, NY: Verso, 1994. 